\title{
The Crystal Structure, Thermal Behaviour and IR Spectrum of Copper Tetraammine Dithionate
}

\author{
MARKKU LESKELÄ and JUSSI VALKONEN
}

Department of Chemistry, Helsinki University of Technology, Otaniemi, SF-02150 Espoo 15, Finland

$\mathrm{Cu}\left(\mathrm{NH}_{3}\right)_{4} \mathrm{~S}_{2} \mathrm{O}_{6}$ crystals were obtained from ammoniacal copper acetate solution which had been saturated with sulfur dioxide. The compound was characterized by chemical and thermal analyses and IR spectra and the crystal structure was determined from three-dimensional X-ray diffraction data. The dithionate crystallizes in the monoclinic space group $P 2_{1} / c$ (No. 14). The cell parameters are $a=7.148(2)$ $b=10.604(3), c=11.675(3) \AA, \beta=145.12(1)^{\circ}, Z=2$. The structure was refined to a final $R$-value of $5.2 \%$.

The structure consists of chains formed by $\mathrm{Cu}-$ octahedra and dithionate groups. The $\mathrm{Cu}$-atom is six-coordinated by four nitrogen atoms and two oxygen atoms at average distances of 2.05 and $2.62 \AA$, respectively.

The existence of copper dithionate and copper tetraammine dithionate has been known a long time. In 1926 De Baat prepared copper dithionate from $\mathrm{BaS}_{2} \mathrm{O}_{6} \cdot 2 \mathrm{H}_{2} \mathrm{O}$ and $\mathrm{CuSO}_{4} \cdot 5 \mathrm{H}_{2} \mathrm{O} .{ }^{1}$ The dithionate ion for $\mathrm{BaS}_{2} \mathrm{O}_{6} \cdot 2 \mathrm{H}_{2} \mathrm{O}$ was prepared from sulfite solution, which had been oxidized with $\mathrm{MnO}_{2}$. This remains one of the standard methods of producing dithionates. A few years later Garreau ${ }^{2}$ prepared $\mathrm{Cu}\left(\mathrm{NH}_{3}\right)_{4} \mathrm{~S}_{2} \mathrm{O}_{6}$ from a solution containing $\left(\mathrm{NH}_{4}\right)_{2} \mathrm{SO}_{3}, \mathrm{NH}_{4} \mathrm{OH}$ and $\mathrm{NH}_{3} \mathrm{Cu}(\mathrm{OH})_{2}$, showing that in alkaline solution sulfite ion can be oxidized to dithionate ion by air alone.

Although the crystal structures of several simple dithionates ${ }^{3-6}$ and those of some complex ones ${ }^{7}$ have been solved, the structures of copper dithionates have remained unknown. Only the IR and molecular spectrum of these compounds have been measured by Duval and Lecomte.,

\section{EXPERIMENTAL}

Crystal preparation and analyses. Crystals suitable for X-ray analysis were obtained by dissolving $2 \mathrm{~g}$ of copper acetate in $50 \mathrm{ml}$ of distilled water and adding $30 \mathrm{ml}$ of ammonia $(25 \%)$. This deep blue solution was saturated with sulfur dioxide by bubbling it through the solution for $1 \mathrm{~h}$. On evaporation of the solution at room temperature dark violet $\mathrm{Cu}\left(\mathrm{NH}_{3}\right)_{4} \mathrm{~S}_{2} \mathrm{O}_{6}$ needles were formed. All reactions were carried out in air so that the oxidation could take place.

Elemental analyses were carried out by Novo Microanalytical Laboratory, Novo Industri A/S, DK-2880 Bagsvaerd, Denmark, supervised by Rolf E. Amsler. Found: $21.59 \% \mathrm{Cu}, 22.29 \% \mathrm{~S}$ and $19.21 \% \mathrm{~N}$. Calc. for $\mathrm{Cu}\left(\mathrm{NH}_{3}\right)_{4} \mathrm{~S}_{2} \mathrm{O}_{6}: 21.77 \% \mathrm{Cu}$, $22.01 \% \mathrm{~S}$ and $19.20 \% \mathrm{~N}$.

The thermal decomposition was investigated in a Mettler thermoanalyzer TA-1 by simultaneous recording of the TG, DTG and DTA curves. The investigations were made both in air and in nitrogen. The flow rate of the gases was $100 \mathrm{~cm}^{3} / \mathrm{min}$ and the heating rates were $6{ }^{\circ} \mathrm{C} \mathrm{min}-1$ and $1{ }^{\circ} \mathrm{C} \mathrm{min}{ }^{-1}$. The sample holder was a platinum crucible (diam. $7 \mathrm{~mm}$, depth $19 \mathrm{~mm}$ ). In DTA measurements alumina was used as reference material.

IR spectrum were measured on a Perkin-Elmer 521 instrument using the $\mathrm{KBr}$ pellet technique.

Structure determination. The $\mathrm{X}$-ray intensities were recorded with a Syntex $P 2_{1}$ (Fortran version) automatic four-circle diffractometer employing graphite monochromatized MoK $\alpha$-radiation. The unit cell parameters were calculated by least-squares refinement of 24 reflections. The intensities of 1845 independent reflections up to $2 \theta$ of $70^{\circ}$ were measured and the 1429 reflections with $I>4 \sigma(I)$ were considered significant. The $\theta / 2 \theta$ scan technique was used and the scan speed was $0.8-3.5^{\circ} / \mathrm{min}$. The intensity, $I$, of each reflection was calculated by subtracting the total background count, BG, 


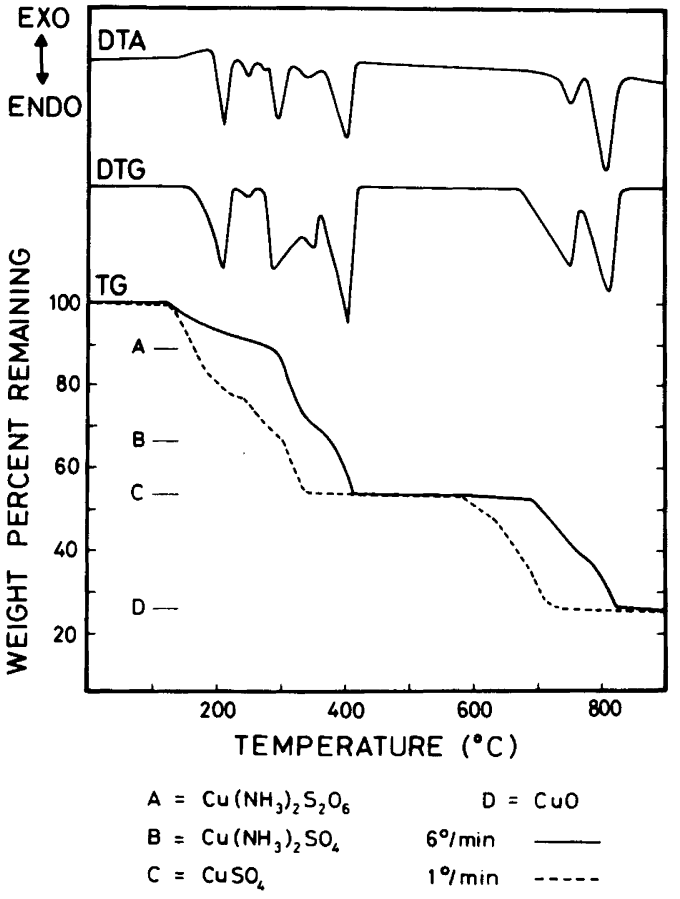

Fig. 1. Thermal decomposition of $\mathrm{Cu}\left(\mathrm{NH}_{3}\right)_{4} \mathrm{~S}_{2} \mathrm{O}_{6}$ in air. Sample weight $53 \mathrm{mg}$.

from the total scan count, SC. The standard deviation, $\sigma(I)$ was obtained from $\sigma(I)=(\mathrm{SC}+\mathrm{BG})^{1 / 2}$. The values obtained were then multiplied with the scan rate to compensate for the different scan speeds. The net intensities were corrected for Lorentz and polarization effects. Empirical absorption correction were made on the basis of the $\phi$-scan data with 9 different $2 \theta$ values. The largest measured relative reduction in intensity was from 1.000 to 0.557 . The systematic absences in the original intensity data indicated the space group $P 2_{1} / c$ (No. 14). The dimensions of the crystal were ap-
Table 1. Infrared absorption frequencies and their assignments in the region $4000-400 \mathrm{~cm}^{-1}$.

\begin{tabular}{ll}
\hline Observed frequency & Assignments \\
\hline $3310 \mathrm{~s}$ & $v_{4}\left(\mathrm{NH}_{3}\right)$ \\
$3220 \mathrm{~s}$ & $v_{1}\left(\mathrm{NH}_{3}\right)$ \\
$2330 \mathrm{vw}$ & $v_{7}+v_{1}\left(\mathrm{~S}_{2} \mathrm{O}_{6}\right)$ \\
$2200 \mathrm{vw}$ & $v_{10}+v_{5}\left(\mathrm{~S}_{2} \mathrm{O}_{6}\right)$ \\
$2085 \mathrm{vw}$ & $v_{1}+v_{5}\left(\mathrm{~S}_{2} \mathrm{O}_{6}\right)$ \\
$1620 \mathrm{~m}$ & $v_{5}\left(\mathrm{NH}_{3}\right)$ \\
$1600 \mathrm{~m}$ & $v_{1}+v_{8}\left(\mathrm{~S}_{2} \mathrm{O}_{6}\right)$ \\
$1390 \mathrm{~m}$ & $v_{1}+290\left(\mathrm{~S}_{2} \mathrm{O}_{6}\right)^{a}$ \\
$1245 \mathrm{vs}$ & $v_{7}\left(\mathrm{~S}_{2} \mathrm{O}_{6}\right) v_{2}\left(\mathrm{NH}_{3}\right)$ \\
$1210 \mathrm{~s}$ & $v_{10}\left(\mathrm{~S}_{2} \mathrm{O}_{6}\right)$ \\
$1090 \mathrm{~m}$ & $v_{1}\left(\mathrm{~S}_{2} \mathrm{O}_{6}\right)$ \\
$995 \mathrm{~s}$ & $v_{5}\left(\mathrm{~S}_{2} \mathrm{O}_{6}\right)$ \\
$780 \mathrm{~m}$ & $v_{11}+204\left(\mathrm{~S}_{2} \mathrm{O}_{6}\right)^{a}$ \\
$700 \mathrm{~s}$ & $v_{6}\left(\mathrm{NH}_{3}\right)$ \\
$565 \mathrm{vs}$ & $v_{1}\left(\mathrm{~S}_{2} \mathrm{O}_{6}\right)$ \\
$510 \mathrm{~s}$ & $v_{8}\left(\mathrm{~S}_{2} \mathrm{O}_{6}\right)$ \\
$420 \mathrm{vw}$ & $v_{3}\left(\mathrm{NH}_{3}\right)$ \\
\hline
\end{tabular}

a The low frequencies of the $\mathrm{S}_{2} \mathrm{O}_{6}^{2-}$ groups are according to Palmer. ${ }^{15}$

proximately $1.0 \times 0.5 \times 0.2 \mathrm{~mm}$.

The positions of $\mathrm{Cu}$ and $\mathrm{S}$ atoms were obtained by direct methods, using the $244 E$-values larger than 1.4. Solving, refinement and plotting were carried out with the X-RAY SYSTEM $1976 .{ }^{10}$ The scattering factors were those of Cromer and Mann for neutral atoms. ${ }^{11}$ After refinement of the positions of $\mathrm{Cu}$ and $\mathrm{S}$ atoms the value of $R$ was 0.288 . The positional parameters of all the oxygens were obtained from the difference Fourier map. The structure was then refined with isotropic temperature factors to an $R$-value of 0.077 and, after blockdiagonal refinement with anisotropic temperature factors, to an $R$-value of 0.052 . No weighting scheme was used, all intensities had a unit weight. The $\left|F_{\mathrm{o}}\right|$ and $\left|F_{\mathrm{c}}\right|$ listing is available from the authors upon request.

Table 2. Atomic coordinates and anisotropic temperature coefficients with their estimated standard deviations. The temperature coefficients are of the form $\exp \left[-2 \pi^{2}\left(h^{2} a^{* 2} U_{11}+\ldots+2 k l b^{*} c^{*} U_{23}\right)\right]$, and have been multiplied by $10^{4}$.

\begin{tabular}{lllllllrrr}
\hline Atom & $x$ & $y$ & $z$ & $U_{11}$ & $U_{22}$ & $U_{33}$ & \multicolumn{1}{c}{$U_{12}$} & $U_{13}$ & \multicolumn{1}{c}{$U_{23}$} \\
\hline $\mathrm{Cu}$ & 0 & 0 & 0 & $271(5)$ & $232(4)$ & $289(5)$ & $8(4)$ & $240(4)$ & $5(4)$ \\
S1 & $.8638(4)$ & $.0322(1)$ & $.3591(2)$ & $240(6)$ & $280(6)$ & $270(6)$ & $24(5)$ & $209(6)$ & $36(5)$ \\
O1 & $.4161(11)$ & $.5986(5)$ & $.2331(7)$ & $255(21)$ & $381(25)$ & $345(24)$ & $-93(18)$ & $220(21)$ & $-60(19)$ \\
O2 & $.7798(13)$ & $.9161(5)$ & $.2547(7)$ & $442(30)$ & $492(31)$ & $344(26)$ & $35(24)$ & $314(25)$ & $-67(22)$ \\
O3 & $.0899(13)$ & $.1151(5)$ & $.4107(8)$ & $374(27)$ & $571(34)$ & $448(30)$ & $-23(24)$ & $338(27)$ & $136(25)$ \\
N1 & $.8427(15)$ & $.3912(6)$ & $.2877(9)$ & $388(31)$ & $367(29)$ & $338(28)$ & $-25(23)$ & $313(27)$ & $-55(22)$ \\
N2 & $.0830(15)$ & $.6493(5)$ & $.4339(9)$ & $496(36)$ & $284(26)$ & $469(35)$ & $-12(24)$ & $424(32)$ & $26(23)$ \\
\hline
\end{tabular}




\section{RESULTS AND DISCUSSION}

Thermal analysis. With the heating rate of $6 \%$ min there is first an endothermic reaction in the temperature range $160-230{ }^{\circ} \mathrm{C}$ (Fig. 1). The observed weight loss corresponds to two ammonia molecules. In the following stage dithionate decomposes to sulfate and sulfur dioxide is released. Then the two other ammonia molecules are released. At $410{ }^{\circ} \mathrm{C}$ there remains only anhydrous copper sulfate, which decomposes as expected in two stages to copper oxide in the temperature range of $690-$ $820^{\circ} \mathrm{C}$. The decomposition was found to proceed similarly in nitrogen atmosphere.

When the heating rate is $1 \%$ min the four ammonia molecules and sulfur dioxide are released in succession so that clear plateaus between the different decomposition stages are not found. As expected, the reactions take place in a temperature range which is $50-80{ }^{\circ} \mathrm{C}$ lower than with the higher heating rate.

The results of the thermal analyses correspond well with those obtained by Liptay for zinc tetraammine dithionate. ${ }^{12}$

Infrared analysis. The IR spectrum of copper tetraammine dithionate showed the normal frequencies of the symmetries $C_{3 v}$ for $\mathrm{NH}_{3}$ and $D_{3 d}$ for $\mathrm{S}_{2} \mathrm{O}_{6}{ }^{2-}$ (Table 1). ${ }^{13-15}$ Outside the investigated range were the following: $\mathrm{S}-\mathrm{S}$ stretching at 290 $\mathrm{cm}^{-1}, \mathrm{SO}_{3}$ rocking at $205 \mathrm{~cm}^{-1}$ and $\mathrm{SO}_{3}-\mathrm{SO}_{3}$ torsion at $155 \mathrm{~cm}^{-1} .15$

Structure analysis. The positional and thermal parameters for nonhydrogen atoms are given in Table 2 and crystal data in Table 3 . The $\mathrm{Cu}$ atom is
Table 3. Crystal data for $\mathrm{Cu}\left(\mathrm{NH}_{3}\right)_{4} \mathrm{~S}_{2} \mathrm{O}_{6}$.

\begin{tabular}{ll}
\hline Formula & $\mathrm{Cu}\left(\mathrm{NH}_{3}\right)_{4} \mathrm{~S}_{2} \mathrm{O}_{6}$ \\
Formula weight & 291.79 \\
Lattice constants & $a=7.148(2)$ \\
$(\AA)$ & $b=10.604(3)$ \\
$(\AA)$ & $c=11.675(3)$ \\
$\left({ }^{\circ}\right)$ & $\beta=145.12(1)$ \\
Cell volume $\left(\AA^{3}\right)$ & $V=506.1(2)$ \\
Molecules per unit cell & $Z=2$ \\
Space group & $P 2_{1} / c($ No. 14$)$ \\
Density $\left(\mathrm{g} \mathrm{cm}^{-3}\right)$ & $D_{x}=1.915$ \\
Linear absorption & $\mu(\mathrm{MoK} \alpha)=26.7$ \\
coefficient $\left(\mathrm{cm}^{-1}\right)$ & \\
\hline
\end{tabular}

Table 4. Distances $(\AA)$ and angles $\left({ }^{\circ}\right)$ around the $\mathrm{Cu}$ atom.

\begin{tabular}{lllll}
\hline $\mathrm{Cu}-\mathrm{O} 1$ & $2.624(5)$ & $\left({ }^{*} 2\right)$ & $\mathrm{N} 1-\mathrm{Cu}-\mathrm{N} 2$ & $91.2(4)$ \\
$\mathrm{Cu}-\mathrm{N} 1$ & $2.041(10)$ & $\left({ }^{*} 2\right)$ & $\mathrm{O} 1-\mathrm{Cu}-\mathrm{N} 1$ & $91.6(3)$ \\
$\mathrm{Cu}-\mathrm{N} 2$ & $2.050(10)$ & $\left({ }^{*} 2\right)$ & $\mathrm{O} 1-\mathrm{Cu}-\mathrm{N} 2$ & $94.9(3)$ \\
\hline
\end{tabular}

Table 5. Distances $(\AA)$ and angles $\left({ }^{\circ}\right)$ in the dithionate group.

\begin{tabular}{llll}
\hline $\mathrm{S}-\mathrm{O} 1$ & $1.457(8)$ & $\mathrm{O} 1-\mathrm{S}-\mathrm{O} 2$ & $114.4(4)$ \\
$\mathrm{S}-\mathrm{O} 2$ & $1.470(7)$ & $\mathrm{O} 1-\mathrm{S}-\mathrm{O} 3$ & $113.4(4)$ \\
$\mathrm{S}-\mathrm{O} 3$ & $1.467(9)$ & $\mathrm{O} 2-\mathrm{S}-\mathrm{O} 3$ & $113.9(6)$ \\
$\mathrm{S}-\mathrm{S}$ & $2.138(4)$ & $\mathrm{S}-\mathrm{S}-\mathrm{O} 1$ & $104.9(4)$ \\
& & $\mathrm{S}-\mathrm{S}-\mathrm{O} 2$ & $104.2(3)$ \\
& & $\mathrm{S}-\mathrm{S}-\mathrm{O} 3$ & $104.7(3)$ \\
\hline
\end{tabular}

Table 6. Interatomic $\mathrm{S}-\mathrm{O}$ and $\mathrm{S}-\mathrm{S}$ distances in some dithionates.

\begin{tabular}{lllc}
\hline Compound & $\mathrm{S}-\mathrm{S}$ distances $(\AA)$ & $\mathrm{S}-\mathrm{O}$ distances $(\AA)$ & Ref. \\
\hline $\mathrm{Li}_{2} \mathrm{~S}_{2} \mathrm{O}_{6} \cdot 2 \mathrm{H}_{2} \mathrm{O}$ & 2.14 & $1.447-1.457$ & 4 \\
$\mathrm{Na}_{2} \mathrm{~S}_{2} \mathrm{O}_{6} \cdot 2 \mathrm{H}_{2} \mathrm{O}$ & 2.15 & $1.450-1.463$ & 4 \\
$\mathrm{Na}_{2} \mathrm{~S}_{2} \mathrm{O}_{6} \cdot 2 \mathrm{H}_{2} \mathrm{O}$ & 2.141 & $1.450-1.457$ & 25 \\
$\mathrm{~K}_{2} \mathrm{~S}_{2} \mathrm{O}_{6}$ & $2.14-2.15$ & $1.42-1.43$ & 16 \\
$\mathrm{MgS}_{2} \mathrm{O}_{6} \cdot 6 \mathrm{H}_{2} \mathrm{O}$ & 2.123 & $1.447-1.449$ & 17 \\
$\mathrm{BaS}_{2} \mathrm{O}_{6} \cdot 2 \mathrm{H}_{2} \mathrm{O}$ & 2.15 & 1.46 & 5 \\
$\mathrm{NiS}_{2} \mathrm{O}_{6} \cdot 6 \mathrm{H}_{2} \mathrm{O}$ & 2.123 & $1.446-1.454$ & 17 \\
$\mathrm{ZnS}_{2} \mathrm{O}_{6} \cdot 6 \mathrm{H}_{2} \mathrm{O}$ & 2.127 & $1.448-1.453$ & 17 \\
$\mathrm{NaK}_{2} \mathrm{ClS}_{2} \mathrm{O}_{6}$ & 2.08 & $1.44-1.50$ & 7 \\
$\mathrm{NaK}_{5} \mathrm{Cl}_{2}\left(\mathrm{~S}_{2} \mathrm{O}_{6}\right)_{2}$ & 2.08 & $1.47-1.49$ & 7 \\
{$\left[\left(\mathrm{NH}_{3}\right)_{3} \mathrm{Co}(\mathrm{OH})_{3} \mathrm{Co}\left(\mathrm{NH}_{3}\right)_{3}\right]_{2}\left(\mathrm{~S}_{2} \mathrm{O}_{6}\right)_{3}$} & $2.119-2.138$ & $1.441-1.455$ & 19 \\
$\left(\mathrm{NH}_{4}\right)_{3} \mathrm{ClS} \mathrm{S}_{2} \mathrm{O}_{6}$ & $2.13-2.16$ & $1.41-1.53$ & 18 \\
{$\left[\left(\mathrm{Cr}(e n)_{2}(\mathrm{OH})\right)_{2}\right]\left[\mathrm{S}_{2} \mathrm{O}_{6}\right]_{2}$} & 2.127 & $1.435-1.460$ & 20 \\
$\mathrm{Cu}\left(\mathrm{NH}_{3}\right)_{4} \mathrm{~S}_{2} \mathrm{O}_{6}$ & 2.138 & $1.457-1.470$ & This work \\
\hline
\end{tabular}

Acta Chem. Scand. A 32 (1978) No. 9 
Table 7. Interatomic distances between $\mathrm{Cu}-\mathrm{O}$ and $\mathrm{Cu}-\mathrm{N}$ atoms in some copper tetraammine compounds.

\begin{tabular}{llll}
\hline Compound & $\mathrm{Cu}-\mathrm{O}(\AA)$ & $\mathrm{Cu}-\mathrm{N}(\AA)$ & Ref. \\
\hline $\mathrm{Cu}\left(\mathrm{NH}_{3}\right)_{4} \mathrm{SO}_{4} \cdot \mathrm{H}_{2} \mathrm{O}$ & $2.339(9)$ & $2.031(6)-2.032(6)$ & 21 \\
$\mathrm{Cu}\left(\mathrm{NH}_{3}\right)_{4} \mathrm{SeO}_{4}$ & $2.607(7), 2.451(8)$ & $1.992(1)-2.017(9)$ & 21 \\
$\mathrm{Cu}\left(\mathrm{NH}_{3}\right)_{4}\left(\mathrm{NO}_{3}\right)_{2}$ & $2.517(5)-2.706(7)$ & $2.008(5)-2.029(5)$ & 22 \\
$\mathrm{Cu}\left(\mathrm{NH}_{3}\right)_{4} \mathrm{~S}_{2} \mathrm{O}_{6}$ & $2.624(5)$ & $2.041(10)-2.050(10)$ & Present work \\
\hline
\end{tabular}

Table 8. Distances $(\AA)$ around nitrogen atoms (less than $3.3 \AA$ ).

\begin{tabular}{rl}
\hline $\mathrm{N} 1-\mathrm{N} 2$ & $2.863(14)$ \\
$-\mathrm{N} 2$ & $2.922(8)$ \\
$-\mathrm{O} 3$ & $3.097(8)$ \\
-O1 & $3.279(6)$ \\
$-\mathrm{O} 2$ & $3.128(14)$ \\
-O3 & $3.078(8)$ \\
& \\
$\mathrm{N} 2-\mathrm{O} 2$ & $2.952(10)$ \\
-O1 & $3.189(14)$ \\
-O2 & $3.105(8)$ \\
-O3 & $3.113(14)$ \\
\hline
\end{tabular}
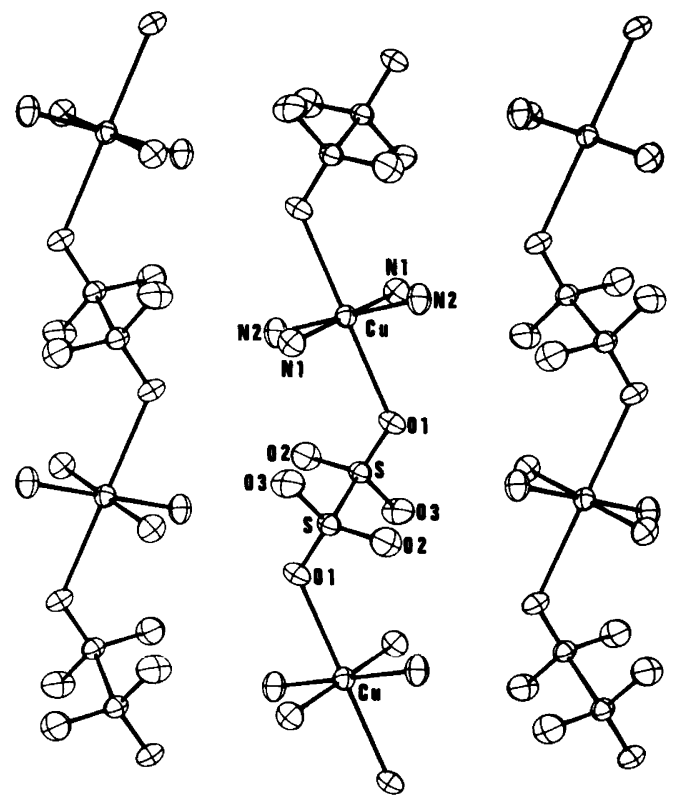

Fig. 2. Perspective drawing showing the chain structure of $\mathrm{Cu}\left(\mathrm{NH}_{3}\right)_{4} \mathrm{~S}_{2} \mathrm{O}_{6}$. The $x$-axis is vertical and the $y$-axis horizontal. six-coordinated, of type $4+2$; the four nitrogen atoms of the ammine group lie about $2.0 \AA$ from $\mathrm{Cu}$, forming a square planar arrangement around it, while the two oxygen atoms of the dithionate group are situated at a distance of about $2.6 \AA$ (Table 4). The $\mathrm{O} 1$ atoms are above and below this plane. The $\mathrm{Cu}$ atoms are situated at the centres of symmetry. All distances are quite normal compared with other $\mathrm{Cu}$ compounds of the same type (Table 7).

The dithionate group consists of two $\mathrm{SO}_{3}$ polyhedra connected together centrosymmetrically by an $\mathrm{S}-\mathrm{S}$ bond of $2.138 \AA$. The $\mathrm{S}-\mathrm{O}$ distance is slightly shorter than in sulfites (about $1.5 \AA$ ), ${ }^{23}$ probably due to the second sulfur atom (Table 5). The distance between the sulfur atoms is longer than usual (about 2.06) ${ }^{24}$ but this is observed in all dithionates (Table 6).

The structure consists of chains formed by dithionate and copper atoms (Fig. 2). These $\mathrm{Cu}-\mathrm{O} 1-\mathrm{S}-\mathrm{S}-\mathrm{O} 1-\mathrm{Cu}$ chains are perpendicular to the $y z$-plane and are joined together by hydrogen bonds to ammine groups. Hydrogen atoms could not be located but the possible hydrogen bond distances listed in Table 8 are in good agreement with the distances given for $\mathrm{Cu}\left(\mathrm{NH}_{3}\right)_{4} \mathrm{SO}_{4} \cdot \mathrm{H}_{2} \mathrm{O}$ and $\mathrm{Cu}\left(\mathrm{NH}_{3}\right)_{4} \mathrm{SeO}_{4}{ }^{21}$ and $\mathrm{Cu}\left(\mathrm{NH}_{3}\right)_{4}\left(\mathrm{NO}_{3}\right)_{2} .{ }^{22}$

\section{REFERENCES}

1. De Baat, W. C. Recl. Trav. Chim. Pays-Bas 45 (1926) 237.

2. Garreau, Y. Bull. Soc. Chim. Fr. 1 (1934) 1563.

3. Van Meerssche, M., Dereppe, J. M. and Lobo, P. W. Acta Crystallogr. 16 (1963) 95.

4. Berthold, I. and Weiss, A. Z. Naturforsch. Teil A 22 (1967) 1440.

5. Rausell-Colom, J. A. and Garcia-Blanco, S. Acta Crystallogr. 21 (1966) 672.

6. Chan, J. and Stanley, E. Z. Kristallogr. 132 (1970) 404

7. Stanley, E. Acta Crystallogr. 6 (1953) 187.

8. Duval, C. and Lecomte, J. C.R. Acad. Sci. Ser. C. 217 (1943) 42. 
9. Duval, C. and Lecomte, J. Bull. Soc. Chim. Fr. 11 (1944) 376.

10. Steward, J. M.,Ed., The X-Ray System, Version of 1976, Technical Report TR-446, Computer Science Center, University of Maryland, College Park.

11. Cromer, D. and Mann, S. Acta Crystallogr. A 24 (1968) 321.

12. Liptay, G. Kem.-Kemi 4 (1977) 387.

13. Vogt, L. H., Katz, J. L. and Wiberley, S. E. Inorg. Chem. 4 (1965) 1157.

14. Nakagawa, I. and Shimanouchi, T. Spectrochim. Acta 22 (1966) 759.

15. Palmer, W. G. J. Chem. Soc. (1961) 1552.

16. Stanley, E. Acta Crystallogr. 9 (1956) 897.

17. Black, W. H., Griffith, E. A. H. and Robertson, B. E. Acta Crystallogr. B 31 (1975) 615.

18. Guttormson, R. J. and Stanley, E. Acta Crystallogr. B 25 (1969) 971.

19. Thewalt, U. Z. Anorg. Allg. Chem. 412 (1975) 29.

20. Cline, S. J., Scaringe, R. P., Hatfield, W. E. and Hodgson, D. J. J. Chem. Soc. Dalton Trans. 17 (1977) 1662.

21. Morosin, B. Acta Crystallogr. B 25 (1969) 19.

22. Morosin, B. Acta Crystallogr. B 32 (1976) 1237.

23. Kierkegaard, P. and Nyberg, B. Acta Chem. Scand. 19 (1965) 2189.

24. Meyer, B. Chem. Rev. 76 (1976) 367.

25. Kiers, C. T., Piepenbroek, A. and Vos, A. Acta Crystallogr. B 34 (1978) 888.

Received May 26, 1978. 